\title{
A world fit for money laundering: the Atlantic alliance's undermining of organized crime control
}

\section{Mary Alice Young ${ }^{1} \cdot$ Michael Woodiwiss $^{1}$}

Published online: 25 April 2020

(C) The Author(s) 2020

\begin{abstract}
This is the untold history of how prominent civil servants in the UK tailored US-devised anti-money laundering (AML) policies in ways that suited the needs of Britain's financial services industry. In the aftermath of these initial compromises in 1987, criminal money managers in both the US and the UK were able to continue to operate in an environment that easily allowed them to hide and use dirty money. The researchers analysed six months of previously unseen personal correspondence and documents exchanged between various actors in the UK Government during 1987. From this they conclude that the core of the current, global AML regime, was not the destruction of drug money laundering and banking secrecy, nor the ending of criminal financial enablers and with it hot money; rather it was the protection and leverage of national trading interests on both sides of the Atlantic. And the drive to protect these interests would see crime control laws made, amended and changed to cater for the interests of the US and UK banking and finance industries. The file had been classified as secret and held by the UK Treasury until it was released to the public in 2017 as an archive document transferred to The National Archives in accordance with The Public Records Act and the Freedom of Information Act.
\end{abstract}

Keywords Money laundering · Organized crime control · Bank secrecy · White collar crime $\cdot$ International law

\section{Introduction}

In the post 9/11 era, there has been a systematic and regular production of anti-money laundering (AML) guidance documents and the creation of various AML programmes from international bodies including the World Bank and the International Monetary Fund

Mary Alice Young

Mary.Young@uwe.ac.uk

1 University of the West of England, Frenchay Campus, Bristol BS161QY, England 
(see for example Schott's Reference Guide to Anti-Money Laundering and Combating the Financing of Terrorism, Schott 2006); the Financial Action Task Force (FATF) (for example, Guidance on Criminalising Terrorist Financing, 2016 and Best Practices on Confiscation (Recommendations 4 and 38) and a Framework for Ongoing Work on Asset Recovery 2012); and the United Nations (UN) (Global Programme against Money Laundering, Proceeds of Crime, and the Financing of Terrorism (GPML) 2007). These 'best practice' initiatives centre on the notion that it is a priority for all countries to establish their own national frameworks to combat the phenomenon of money laundering and the wider concept of financial crime. Countries' own frameworks are constructed in line with international AML standards and benchmarks initially created by the US as part of wider foreign and public policy initiatives to control organized crime.

Assumptions that the US is successful in its efforts to extend and apply the requirements of domestic crime control policies to foreign branches of domestic financial institutions located abroad, tend to be embraced by those who write non-critically about the "international fight against money laundering" and its threat to society, and who believe that the implementation of AML policies offers solutions to a myriad of organized crime problems (see generally, Robinson 1995; Stessens 2000; Fisher 2002; Leong 2007; Souster 2013; Cox 2014). Therefore, the wider literature base remains largely complaisant towards the international AML system and its hoard of "strong tools" such as international cooperation and the exchange of information, thought to be successful in the fight against crime, including corruption (Sharman and Chaikin 2009; Ferwerda, 2009). Sympathetic publications reinforce the misleading narrative of policy makers that organised and financial crime, including money laundering was largely driven by 'traditional' criminal organisations and remains a major threat to the democracy of all nations. As the authors will demonstrate, however, the current international AML framework arose out of expedient compromises that would favour the financial communities of the US and the UK at the expense of genuinely effective organized crime control.

As will be shown in this paper, the "claim makers" (specifically, US and UK policy makers during the administrations of Ronald Reagan and Margaret Thatcher) were successful in creating an internationally palatable AML template, by framing the threat mantra of money laundering, in such a way that it has been adopted by sympathetic, mainstream academics who are then able to bring definitions and concepts "to the public realm" (Ceresola 2019:51). It should be acknowledged that there are notable exceptions to the aforementioned mainstream narratives of the AML system, including critical scholars such as Levi and Reuter (2006), and Van Duyne (2008) who acknowledge that the international AML framework has not had the desired effect of suppressing criminal activities and thwarting organized crime groups. The origins of the AML machine, however, have not yet been examined in depth and the authors of this paper address this gap in the literature. Using primary correspondence data in the form of previously unseen letters between UK bankers and civil servants written during 1987, we seek to illuminate the compromises made as the global AML framework was taking shape. These compromises would come to render the framework as flawed.

Adopting the language of Ceresola (2019), the US has historically been the primary framer and claims-maker, in terms of defining money laundering, deciding the scale of the threat of money laundering, and subsequently, determining that coalitions between banking communities and governments were the best ways - indeed the only ways - to solve the problem of dirty money. Through the analysis of a mix of political and 
financial sector narratives presented in the form of correspondence data (typed letters), and official reports - some of which will be explored in this paper - it will be shown, that those responsible for the creation of the global AML regime have established money laundering as a continuing threat to society; one which is inextricably linked to the illegal drug trade. Having presented this 'threat' to a global audience, policy makers have been able to justify the creation of flawed policies in response to public anxieties which largely evolve from the media's distorted presentation of organized crime (Greer 2013). As the research for this paper will reveal, the public presentation of the conceptualisation of the threat of money laundering and its control has grown, initially, from deals and compromises between US and UK policy makers. These compromises, shaped and moulded a global AML regime tailored to fit the US' and UK's own banking and finance trading priorities, using the war on drugs and thus organized crime, as a handy smokescreen. The US government was then largely responsible for setting the organized crime control agendas of national governments and international organisations, notably the UN, the FATF, the Basel Committee on Banking Supervision (BCBS), and international law enforcement agencies such as Interpol.

Within the policy making process, the framing of "public goods and public evils has ramifications for laws, legislation, and funding that affects individuals on the ground" (Ceresola 2019:52). This is the first known paper, using primary source correspondence data, to detail the reasons why US devised policies concerning money laundering controls in the 1970s and 1980s, were not initially acceptable to the UK and how compromises between both countries were engineered to deliver a palatable AML system, still in use today and protecting the richest countries. In the course of researching for this paper, the authors have uncovered that the framing of money laundering by the US in the 1970s and 1980s had numerous ramifications, including adopting the war on drugs as a political veil to justify targeting foreign tax havens as conduits of organized crime and money laundering. This tactic was also favoured by the UK which wanted to retain its wealthy tax haven territories with their secrecy laws, but also wished to be seen to be doing something about the war on drugs. Ultimately, the handy shield of the international war on drugs and dirty money, led to the creation of AML-focused bodies that rarely challenged the interests of those nations who were complicit in the establishment and maintenance of secrecy havens, and in so doing, elevated the role of bankers to criminal law policy makers while minimising the role of international law enforcement bodies such as Interpol. As will be shown, the ramifications discussed below, are relevant today because in the context of organized crime control at the wider level, the UK and US are still operating with the same assumptions and policies in the twenty-first Century.

In formulating a global AML template during the 1980s, the US's public and foreign policy interests concerning the fight against drug money laundering acted as useful and morally righteous fronts for the real, self-serving interests of the US, which included boosting the wealth of national banking corporations and the government, and halting capital outflows from the US to foreign tax havens as citizens sought to maximise personal wealth by circumventing domestic tax laws. In seeking to recoup tax revenues, the US would be required to take action against the tax and secrecy havens hosting foreign branches of domestic financial institutions; institutions used by Americans and located in British overseas territories such as the Cayman Islands, Bermuda and the Turks and Caicos Islands. In response to threats of extra territorial jurisdiction, and in a 
bid to retain its dominance as a global financial services provider - not to mention the offshore wealth residing in its overseas jurisdictions - the UK was able to accommodate US proposals when compromises were made between both countries, which saw policies amended to present less of a threat to the financial services industries and economies of both countries.

This is the untold and previously secret history of how civil servants in the UK tailored US-devised AML policies to suit the needs of Britain's financial services industry. Further, in the aftermath of 1987, criminal money managers in both the US and the UK continue to operate in an environment that easily allows them to hide and use dirty money.

\section{Methodology}

The researchers analysed six months of previously unseen personal correspondence and documents exchanged between various actors in the UK Government during 1987; letters and documents which formed part of a secret Treasury file, with the file beginning on 28 July 1987 and ending on 23 December 1987 (International Money Laundering: Banking Secrecy, 1987 T555/19 FIM-BNK /A /0012/001 (Document identifier)). The file had been classified as secret and held by the UK Treasury until it was released to the public in 2017 as an archive document transferred to The National Archives in accordance with the Public Records Act 1958 and the Freedom of Information Act 2000.

The personal correspondence used for this research, takes the form of typed letters, sometimes containing handwritten annotations such as underlining important sentences, and comments added by the receiver of the letter. This correspondence data forms part of the archived, previously confidential, Treasury file which contains 379 pages detailing the processes which led to the creation of the current international AML regime. Specifically, the archive comprises of 38 typed letters spanning the aforementioned dates, and it is these which informed the thematic direction of the present article. It should also be mentioned at this juncture, that a large number of the pages in the archive file are replicated policy documents which have been copied into various letters of correspondence as appendices, and that the authors sought to interpret the letters within the wider context of the accompanying policy documents. The numerous reports, including those from the US Treasury, British Bankers Association (BBA) and Interpol, were identified in the archive and also comprise the main sources used for this article.

While archive data has traditionally played a secondary role in qualitative sociolegal research, in the context of this paper - especially given that the document has not yet been publicly discussed and only became publicly available in 2017 - the archive used for the research will adopt the status of a primary resource. The literature on the use of correspondence data as a qualitative method of primary data collection is extremely limited as noted by Harris, who also observed that the "use of correspondence as a primary data collection method in qualitative research is very new" (Harris 2002:1), although Atkinson and Coffey were early advocates who regarded documentary materials as "data in their own right" (Atkinson and Coffey 1997:46) - ergo, primary data. It is the anonymity afforded to the participant which allows the researcher 
to collect data through the form of letters, and thus the participant remains invisible. However, in the context of this project, the letter writers are authors of epistles on advantageous banking and finance strategies in 1987, and their names along with the letters, are publicly available. They will not, nor should they remain invisible participants in the unfolding of this discussion on the creation of the international AML framework.

However, the main dilemma for the researcher collecting data from anonymous participants, remains the same for the authors of this paper; that ultimately, the authors of the letters remain unknown to the researchers in person and so the task has been to interpret the data of complete strangers and the policy making documents which were also made available. The authors of this paper do not disregard the potential limitations of drawing upon historical data gathered from a small pool of letter writers, including the potential for confirmation bias. However, those who critique the article as such, may wish to reflect on how reality can be constructed to support the vested interests of policy makers or "claim-makers" (Spector and Kitsuse 2001; Ceresola 2019:51). Ultimately, an objective of the present study was to examine the influence of relevant civil servants and bankers in shaping criminal law policies which are still in force today. In the historical letters, the researchers have managed to uncover some of the feelings and thoughts of those at the very top of the UK's banking and finance community, when faced with threats to that particular industry.

Letters were written by, sent to, copied to, and/or exchanged between the following parties (names and title as of 1987). It should be highlighted that the list of names below, includes all of those involved in the unfolding dialogue on drug trafficking and money laundering contained in the archive document. When the authors of this article mined the data, they found that some actors were found to be more verbal than others in terms of their views and opinions concerning UK-US agreements on money laundering and drug trafficking:

1. W. Bohan, Home Office;

2. C. Hudson, Home Office;

3. J. Potts, C4 Division, Home Office;

4. B. Bucknell, Economics Relations Department, Foreign and Commonwealth Office;

5. R. Street, Economics Relations Department, Foreign and Commonwealth Office;

6. T. Richardson, Head of the Economics Relations Department, Foreign and Commonwealth Office;

7. T. Harris, British Embassy, Washington DC;

8. R. Lomax, Under Secretary HM Treasury;

9. C. Gregory, The Treasury Solicitor, Queen Anne's Chamber;

10. D. Board, Treasury Chambers;

11. G. Kentfield, Banking Department, Bank of England;

12. R. Farrant, Banking Supervision Division, Bank of England;

13. W. Norton, Secretary, Review of Banking Services Law, Bank of England.

14. C. Kerse, Department of Trade and Industry;

Before the discussion concerning the UK's response to US efforts to implement and enforce a global AML regime as part of the ongoing war on drugs, it is important to 
first address and understand why hot money was such an issue for the US prior to 1987 and the historical evolution of relevant organized crime control policies before this date.

\section{Evolution of US anti-money laundering control: 1970}

The US is particularly relevant for the research for this paper (not least because correspondence to, from and about the US, forms a substantial part of the archival data), but also because the article is primarily concerned with uncovering the compromises behind the creation and spread of the international AML regime. The templates for international drug, organized crime and money laundering control were constructed fifty years ago during the administration of US President Richard Nixon (1969-1975). Criminal justice and law enforcement policies and practices that are now commonplace throughout the world derived from an unprecedented effort to Americanise international law enforcement along lines first articulated by Nixon and his advisers, notably in 1970, when Congress passed both the Organized Crime Control Act (OCCA), and the Comprehensive Drug Abuse Control Act (Young and Woodiwiss 2019:93). These Acts contained substantial and far reaching powers for law enforcement agencies to follow the money and therefore forfeit criminal assets. Most relevant for this paper, the Currency and Foreign Transactions Reporting Act - better known as the Bank Secrecy Act - was also passed in 1970, requiring banks and other financial entities in the US to maintain records and file currency transaction and suspicious activity reports.

\section{US concerns over foreign bank secrecy: 1970}

In 1970, US policymakers and the law enforcement community were united in their view that the Bank Secrecy Act was an essential tool in the fight against international financial crime, and pinpointed financial secrecy provisions in foreign locations (notably tax havens) as the main cause for a proliferation of white collar crime. A 1970 House of Representatives Report on Banks, Records and Foreign Transactions - which was subsequently referred to in a Senate Committee's 1983 report on offshore bank secrecy stated that, "[s]ecret foreign bank accounts and secret foreign financial institutions have permitted a proliferation of "white collar" crime" and that foreign financial secrecy also financially underpinned "organized criminal operations in the United States" (Senate Committee 1983:3). Not only did the 1970 Report identify that foreign financial secrecy enabled organized crime groups to flourish, but it also highlighted how the same secrecy laws allowed normal Americans, "to evade income taxes, conceal assets illegally and purchase gold;... and others to avoid the law and regulations governing securities and exchanges", concluding that secret foreign bank accounts and secret foreign financial institutions have generally, "served as essential ingredients in fraud including schemes to defraud the United States" (Senate Committee 1983:3). Corporate crimes involving "stock acquisitions, mergers and takeovers", and conspiracies to steal from the US defense and foreign aid funds, were also, according to the report, enabled because of foreign bank secrecy (Senate Committee 1983:3). Thus, the 1970 Report was clear in stating the economic harm incurred by Americans because of "these secret institutions", whereby it was reported that, "hundreds of millions in tax revenues have been lost" 
(Senate Committee 1983:3). This loss was undoubtedly facilitated by, "corporation directors, officers and employees who through deceit and violation of law, enriched themselves or endangered the financial soundness of their companies to the detriment of their stockholders" (Senate Committee 1983:3).

Such white collar criminals were in turn allowed to operate their financial affairs with impunity because of the secrecy offered by foreign jurisdictions with mushrooming financial centres. For the Americans, not only did foreign secrecy jurisdictions allow a variety of organised crimes to flourish and be profitable, but these secrecy jurisdictions doubled as foreign tax havens which offered "a range of opportunities" reflecting "the range of clients whose funds seek anonymous emigration from US shores" (Blum 1981:71).

In the early 1970s, the Nixon Administration looked set to tackle the issue of bank secrecy - albeit secrecy located abroad - as part of the wider war on drugs, but this objective itself was set within a broader concern of the threat posed to US tax revenues "from foreign-based companies controlled by United States taxpayers" using foreign tax havens (Blum 1981:72); a concern which Blum dates to 1962 when the US Congress "enacted legislation... which fought to recapture the gains attributable to un-taxed foreign-based company incomes" (Blum 1981:72). The US expansion of the war on drugs to the international fight against money laundering was therefore rooted in halting the threat to tax revenues and stopping capital outflows; the war on drugs and drug money, served as a convenient and morally righteous cause which would be adopted by other Western countries such as the UK.

In summary, it was the Nixon administration which began the criminalisation of money laundering, by supporting legislation designed to enable the tracing of dirty money. The creation of the three acts listed above, together with the Nixon administration's diplomatic and organisational strategies (Nadelmann 1993:145-8; Woodiwiss 2005:136-140) highlighted the US' intention to create a global organized crime control template. However, for US AML policies to ultimately have an international reach, the country would first be required to expand the war on drugs and frame their efforts in such a way as to become the main preoccupation of global law enforcement bodies and other governments.

However, as detailed elsewhere by Young and Woodiwiss (2019), in their article on the effect of US policy making in Caribbean small island developing states, the raft of crime control legislation being created by the US during the 1970 s, meant that socioeconomically and politically fragile drug producing and/or trafficking countries would be subject to various sanctions, including the withdrawal of American aid and increases in duties and tariffs, if those countries failed to cooperate with US drug prohibition policies. In other words, less powerful nations had to comply with American demands on drugs or be economically squeezed. As will be shown in the course of this article, rich nations such as the UK which eased the process of drug money laundering through the provision of financial secrecy products, were not to be penalised.

\section{Failure of the US Bank Secrecy Act: 1983}

In 1983, thirteen years after the passage of the Bank Secrecy Act when the House of Representatives stated a case for the end of bank secrecy, the US Senate Committee on 
Governmental Affairs published a damning study of Crime and Secrecy: The Use of Offshore Banks and Companies. The report detailed how the Bank Secrecy Act and its administration had been a "monumental failure", and concluded that the provisions contained in the Act had failed, "to measurably slow, much less halt, movements of illegally derived currency from the US" (Senate Committee 1983:137). Furthermore, "the Act had failed to yield sufficient data about onshore and offshore money laundering for the adequate formulation of policy or for the development of appropriate legislative, administrative and diplomatic remedies" (Senate Committee 1983:137). The Senate Committee's study on the secret world of offshore finance, made it pertinently clear that smokescreens allowed by "foreign commercial secrecy laws" were the main reason why drug trafficking and organised criminality were flourishing. The study concluded that the problem of bank secrecy was "extensive" and "expanding" and stated that bankers, lawyers, politicians and gangsters used offshore banking facilities as part of organised criminal enterprises (Senate Committee 1983:137).

The subsequent hearings on crime and secrecy before the Permanent Subcommittee on Investigations of the Committee on Governmental Affairs in March and May 1983, addressed such critical issues as the secret movement of illegal wealth at the global level, the use of bank and commercial secrecy and blocking laws in offshore jurisdictions to conceal dirty money, and the difficulties encountered by US law enforcement authorities in attempting to interdict criminal money outflows and inflows or to penetrate the offshore secrecy veil. Most relevant for this article, the hearings also addressed the "collision of US government interests, policies, and practices with those of the "secrecy" countries" - countries where the criminal was deemed able to escape with their illicitly generated wealth intact (Senate Committee 1983:iii).

Foreign bank secrecy was framed by the US in the early 1980s as presenting "a threat to the public's safety" (Senate Committee 1983:iii) because it was deemed as an enabler of serious and organised crimes which impacted on the US and wider society. The Senate Committee in 1983 demanded a tough response to foreign bank secrecy, along the lines articulated in a 1981 report on Tax havens and their use by United States taxpayers, which had been prepared by Richard Gordon (an international tax lawyer employed by the US Treasury). Gordon's report set forth a range of policy recommendations to address the problem of abusive secrecy havens including the possible use of coercive sanctions. These proposals, the Senate Committee's study noted, constituted economic warfare and elaborated that they would, "create an uproar with our allies and trading partners whose airlines, banks, or treaty-shopping US investors would be disadvantageously affected; some would create outrage among US corporations disadvantaged in competition with foreign concerns" (Senate Committee 1983:135-6).

Since several of the best-known secrecy countries were, and remain, the British Overseas Territories (BOTs), it can be observed from the research carried out for this paper, that the minds of British policy makers in 1987 were concentrated on preventing the US threat to Britain's flourishing banking and finance industry: an industry which was thriving because of the financial secrecy and advantageous tax laws offered by subnational island jurisdictions, such as the Cayman Islands and Bermuda, (Young 2012:137) which benefitted (and continue to do so) from their affiliation with the UK as their metropolitan patron (Baldacchino and Milne 2000). As asserted by the British Bankers' Association in August 1987 in their response to the US's proposed 
code of conduct on money laundering (discussed in detail below and contained in the UK Treasury secret file) and referencing Lord Mansfield's still valid dictum of 1775: "the courts of this country do not enforce the revenue laws of another country". As will be shown in this paper, the issues surrounding the extra territorial enforcement of tax claims, would become bargaining chips as the US sought to advance its policies into other countries.

\section{UK acknowledges US concerns over money laundering: 1984-1985}

As has been shown, US policies created in the 1970s, acted as a centrifugal point for the wider, global war on drugs. A point from which all other Western supported assumptions and policies concerning organized crime and its control would stem, including AML policies. Indeed, without the US passing a collective of domestic legislation such as the 1970 Acts discussed above, it is likely that the UK would have remained happily ignorant about these 'new crimes' of money laundering. In fact, a search of the debates conducted in Parliament during the 1970s, exemplifies the lack of awareness that the UK had with regards drug money laundering until the mid-1980s. In 1979, the term "laundering" was referred to in the House of Lords, as an alternative, but not criminal way, for the Russians to trade Rhodesian (now Zimbabwean) chrome without importing it, as part of a wider discussion concerning the US view on laundering as a criminal activity. Therefore, by the late 1970s, the UK government was generally unconcerned by this new concept of laundering goods and assets, unless pressed to address the issue by "American friends" (Lord Paget of Northampton, 1979).

However, in 1985, the House of Commons was referring to policy lessons taught by their American friends, when discussing the "laundering" of money" stemming from "profits made by traffickers in hard drugs" which "are so great that their disposal has become a major problem" (House of Commons, Fifth Report from the Home Affairs Committee, Session 1984-85, Misuse of Hard Drugs (Interim Report):v). In particular, the UK legislature was eager to stop the international flow of laundered drug money in 1985, and suggested the radical step of reforming international banking law to eradicate bank secrecy - indicating the potential for a paradigm shift in the construction of the UK's banking and finance industry. The Fifth Report (1985:vi) stipulated that the parliamentary committee was:

" $[\mathrm{N}]$ ot prepared to lend our support to any degree of assistance to the drug traffic, and, accordingly, recommend immediate steps to reform the laws of banking to remove the secrecy which now protects the international drug traffickers and makes the "laundering" of their money easy."

(Emphasis in original.)

"We recognise," the Report noted, "that this will call for a basic and dramatic reform of international banking law.” (Authors' emphasis) (Fifth Report, 1985:vi).

Evidently, in 1985, parliamentarians were acutely aware of the problem of drug money laundering. Relevant to the research for this paper, the Fifth Report clearly highlighted that the UK Government was "impressed" by the advancement of US law in "regard to compulsory provision of information" to better trace narcotics funds, 
including institutional reporting of deposits in excess of US\$10,000, and individual declarations where a person wished to take more than US\$5000 out of the US (1985:v). Recognising that international asset tracing in an "attack on drugs profits" was a "matter with both domestic and international dimensions", the UK Home Affairs Committee supported the removal of financial secrecy laws via a general overhaul of international banking law $(1985: \mathrm{v})$. The admiration of US policies and the support for the removal of secrecy at the international level, may have been supported by the Commons initially, but as will be shown, just two years later in 1987, these ideas were to be strongly rejected and/or amended by those at the Bank of England and also those working in the UK's Treasury Chambers. As evidenced by the research carried out for this paper, the US and UK reached a compromise in 1987, which has allowed them to continuously undermine the AML framework they created, by retaining banking secrecy for their own commercial gain. As will be shown, the UK and the US worked towards a situation of mutual self-interest that would protect the existing trading priorities of both countries' banking and finance industries.

\section{The US Treasury reports on money laundering and bank secrecy: 1987}

On 27 October 1987, the US Anti-Drug Abuse Act 1986 (ADAA), was approved by President Ronald Reagan to become Public Law No: 99-570, more than twelve months after it had been introduced in House on 8 September 1986, and sixteen years after the creation of Nixon's Comprehensive Drug Abuse Control Act. The ADAA was a seminal piece of legislation in the US war on drugs and different to the aforementioned Acts of 1970, because it created a new offence of money laundering extending to acts performed outside, as well as within, the US. Simply put, the newly created ADAA was able to claim extra territorial jurisdiction with respect to the newly defined offences meaning that US organized crime control policies now had a global reach. Together, these relevant money laundering offences, formed what is collectively known as the Money Laundering Control Act of 1986 (MLCA), which was enacted as Title I of the ADAA. According to Gurule (1995:824) the primary intention of Congress in enacting the MCLA was to criminalise the "process by which one conceals the existence, illegal source, or illegal application of income, and then disguises that income to make it appear legitimate" (President's Commission on Organized Crime ( 1984:4).

The codification of the ADAA and the formation of the MLCA, created statutory requirements for the US Treasury to prepare two reports. The first, main, report titled, International Information Exchange on Money Laundering (hereinafter referred to as the US Treasury Report (TR)), was published in full text on 29 July 1987. The US Treasury Report contained the results of discussions on three initiatives to promote international information exchanges on money laundering, including 1) the creation of an Interpol Working Group on money laundering, 2) securing the cooperation of bank supervisory authorities - notably the Basel Committee on Banking Supervision - and 3) the convening of a conference on money laundering to be hosted at the end of the calendar year in 1987, by the US Treasury. Also published on the same date, was a substantial, companion report titled, Money Laundering and the Bank Secrecy Act: The Question of Foreign Branches of Domestic Financial Institutions (hereinafter referred to as the Companion Report (CR)). Both reports were submitted by the Secretary of the Treasury to congressional committees 
on 29 July 1987 (both reports were also included as appendices in the UK Treasury archive file used for this research and therefore disseminated among the letter writers).

The Companion Report comprised of prepared papers and statements from other countries commenting on their own information sharing obligations with the US, concerning the criminal use of foreign branches of US financial institutions. At the beginning of the Companion Report, in the summary, the US posed three questions:

"As required by the statute the report addresses three questions: (1) the extent to which foreign branches of domestic institutions are used to facilitate money laundering and evasion of the reporting requirements of the Bank Secrecy Act; (2) the extent to which United States law applies to foreign branches of domestic institution; and (3) the methods available for cooperation with the host countries of these financial institutions in money laundering and Bank Secrecy Act cases" (CR 1987:1).

The statutory requirement for the US Secretary of the Treasury to compile these extensive reports on the exchange of information relating to the investigation of money laundering and bank secrecy, indicates just how closely the US was monitoring the efforts of other countries in the war against drugs and dirty money - including financial crimes which were deemed harmful to the US, notably tax evasion. Indeed, the US sought information from countries including the UK concerning the issue of bank secrecy. The initiatives and questions noted above are relevant for this paper, because they acted as a catalyst for high level, secret, discussions between civil servants and bankers in the UK, concerning the UK's commitment to tackling dirty money, while at the same time maintaining bank secrecy. These discussions are contained within the letters which comprise the primary data used to inform the proceeding sections of this paper.

\section{"Seen to be doing something about money laundering"}

As already mentioned, a statutory requirement of the ADAA was for the US Treasury to compile the Companion Report which detailed the cooperation of other countries with the US in light of the Bank Secrecy Act requirements on information sharing. In the summer of 1987, UK Treasury Solicitor, Colin Gregory, prepared a paper titled Bankers Duty of Secrecy which was sent to Tom Harris, the UK Representative at the British Embassy in Washington DC, who then passed it onto the US for inclusion in the Companion Report. An abbreviated version of Gregory's paper was included in Appendix $\mathrm{B}$ of the report, which dealt with the foreign bank secrecy laws of other countries. Appendix $\mathrm{C}$ dealt with the relevant representative blocking statutes of other countries which were deemed as severely limiting the extra territorial enforcement of US AML policies. Simply put, the Companion Report, gathered together information on the bank secrecy laws and blocking statutes of other countries which presented as hindrances to the enforcement of US policies directed at combating money laundering, and it is the hindrances emanating from the UK which the present paper will now turn to.

On the 6 August, Tom Harris (British Embassy, Washington DC), wrote to Richard Street at the Economic Relations Department of the Foreign and Commonwealth Office 
(ERD, FCO), concerning the Companion Report's comments in light of the aforementioned question on the extension of US law to foreign branches of domestic institutions. Harris stated, "we can be reasonably pleased with this report", mainly because the report "explicitly warns the Congressional Committees against attempts to enforce US bank reporting requirements outside the territory of the United States" (TR 1987:3). Harris was pleased that the report stated that any efforts by the US to counter international money laundering in the context of drug trafficking, should be "supported by foreign Governments, to avoid the counter-productive results of increased enforcement of 'blocking statutes and serious confrontation between the US and other Governments". The report is also notable, as the UK discussants recognise it as the "first official report of the US Government which has also drawn attention to the extent to which the United States itself has bank privacy laws".

In the same letter, Harris further noted that the Treasury Report "provides a useful antidote to the more sweeping assertions of potential extra territorial reach which appeared in the conference reports during the passage of the Anti-Drug Bill", indicating that the US was adopting a softer approach in terms of how and when it would apply the ADAA to other countries. The softer approach concerning US extra territorial jurisdiction, was adopted to avoid the "enactment of more stringent blocking laws by the host government and reduction of the market position and influence of U.S. financial institutions in those countries" (CR 1987:11-12). The recognition by the US that it needed to retain its dual position as a leader in the global financial services sector and primary policy maker in the context of the anti-drug AML agenda, is pivotal to the broader discussion in this paper; the US stance highlights that despite outward appearances of strengthening efforts to combat drug money laundering, the US itself had vested interests to ensure that the "market position" of foreign branches of its domestic financial institutions was not compromised in countries where it sought to enforce US law, and that US money did not evade taxes by escaping to domestic financial institutions in foreign tax havens. As noted by Naylor (Naylor 2002:254-5), "(s)tanding in the way were those pesky anti-money-laundering rules, which made the U.S. the least attractive of the major jurisdictions to foreign clients seeking confidentiality", and this aversion also applied to US residents who sought to hide their money and maximise their wealth in offshore secrecy jurisdictions. Therefore, the current, global AML regime has been constructed around the competing interests of the financial services industry. These include domestic banks operating internationally in bids to retain strong market positions, and governmental bodies who wish to recoup tax revenues on illicit proceeds located in foreign secrecy jurisdictions. As revealed in this article, the banking-government relationship is made more complex, because banking corporations wield considerable power within governments and can therefore influence the drafting and passage of laws. Although the mutual dependency of governments and cash-rich corporations is evident, the dependency of both of these groups on criminal wealth is less so. However, banks - operating as they do in the money accumulation business - rely on consistent flows of deposits, whether licit or illicit; this flow of deposits itself relies on attractive laws such as those offering low or no tax burdens, and financial secrecy. Further, governments need banks to prop up economies and therefore state legislatures pass laws to suit the banking sector and which are favourable to the domestic financial services industry. The beneficial relationship that exists between the governments of nation states and their domestic banking corporations and the 
competition between countries to attract and retain wealthy clients, ultimately means that criminal organisations can navigate the global financial architecture in a way that is most advantageous to them, allowing them to transform dirty money into clean assets depending on where the most attractive laws operate. The protection and leverage of various competing trading interests on both sides of the Atlantic (from criminal through to legitimate), are the fundamental building blocks of the current AML framework. The drive to protect the outwardly licit interests, would see crime control laws made, amended and changed to cater for the commercial needs of the US and UK banking and finance industries.

While some in the UK Government, including those in the FCO were pleased with the US', "complimentary references to the cooperation received from the United Kingdom in the fight against narcotics and money laundering" (Harris to Street, 6 August) contained in pages 24, 25 and 67 of the US Treasury Report, those who worked in the UK Government's economic and finance divisions, including HM Treasury, viewed the US as exerting unacceptable extraterritorial jurisdiction in the fight against drugs and dirty money.

Previously, on 29 July 1987 (the same date as the US Treasury Report was published), Rachel Lomax the Under Secretary at HM Treasury, had written to W J Bohan at the Criminal Policy Department in the Home Office, concerning ongoing US/UK negotiations in the context of mutual legal assistance treaties (MLATs) to combat drug trafficking - and by extension the laundering of dirty money. Lomax recognised that Home Office Ministers felt "under strong pressure to reach an early agreement", but cautioned the Home Office's Criminal Policy Department against "signing the agreement on a basis which is likely to mean trouble later on, when the Americans resort to unilateral procedures" therefore highlighting the influence that the UK's banking community exerted in areas of criminal law making. Lomax further elaborated on the reason why HM Treasury was so concerned by these drug trafficking negotiations between the US and UK: "Our main concern is that the UK's position for the future should not be unduly compromised... any recourse by US prosecutors or investigators to the enforcement of the unilateral compulsory processes would be an objectionable extraterritorial action, inconsistent with the spirit of the agreement". Lomax concluded that the UK should not soften its stance regarding the rejection of extraterritorial actions. Lomax again appealed on behalf of HM Treasury, for the Home Office to reject the term "unilateral action" in any agreements made with the US, in a letter dated 25 August and again addressed to Bohan: "it is important to say that unilateral coercion will be regarded as 'unacceptable"'. Subsequently, on returning from annual leave and having seen the correspondence unfolding between Tom Harris and Richard Street, Thomas Richardson from the ERD at the FCO, wrote to Douglas Board at HM Treasury on 8 September 1987. Richardson pertinently noted that in addressing extra territorial concerns, the UK should seek, "indirectly, to persuade other governments of the merits of bilateral agreements to trace, freeze and confiscate drug traffickers' assets... More generally, we want to maintain good relations with the US Treasury..." Richardson concluded that a conference proposed in the US Treasury Report, "has implications for us", given that the scope of the event was to look at the "whole field" of money laundering "and not simply drugs-related money laundering". Simply put, as the US AML machine moved forward, it was becoming clear to those in the UK that any resulting MLATs and other agreements between the two countries, would involve widening the focus of the AML agenda from drugs trafficking to a range of financial crimes including tax frauds. 
For Lomax and other central figures in the UK banking and finance sectors, the merest whiff of extraterritorial jurisdiction signified a potential threat to the UK's market position in this area - and any threat to secrecy would have been perceived as a threat to the UK's trading priorities. The nexus between the UK's defence of its bank secrecy laws - representing the UK's financial industry and trading power - and the ambitions of the US to "demonstrate that they are doing something" (Harris to Richard Street, ERD, FCO, 6 August 1987) about money laundering, highlights the obfuscation surrounding the creation of a global AML regime; obfuscation which has led to the international acceptance of a flawed AML framework, deemed by the authors to be largely ineffective and not fit for purpose. The proceeding discussion will demonstrate that in 1987 confusion between the UK and US was evident, concerning their respective priorities in creating and implementing AML frameworks; furthermore, this confusion led to compromises and the creation of laws and bodies which continue to affect the present day, global AML agenda.

\section{US requires its foreign branches to assist in the war against drugs and dirty money}

This paper has established that the US was statutorily required to gather information concerning the extent to which United States law applied to foreign branches of its domestic financial institutions - including those foreign branches located in territories under the jurisdiction of the UK. The US Companion Report under Section I addressed the "use of foreign branches to facilitate money laundering and evasion of the Bank Secrecy Act" (CR 1987:17-26). Specifically, Section I focused on, "financial institutions located abroad organized as branches of U.S. financial institutions that are incorporated under domestic law" (CR 1987:12). In compiling the report, the US Treasury needed to obtain evidence from the UK and other countries, in order for the US to "dictate what the law would require of a U.S. branch or other operation of a domestic financial institution to do when faced with a violation of the host country's secrecy or blocking laws" (CR 1987:11). In summary, the US needed to understand how a country like the UK would respond to a breach of its own bank secrecy laws and/ or blocking statutes, if the US suspected that foreign branches of its financial institutions were being used for criminal purposes. It is no wonder that the UK was uneasy about US enquiries into financial secrecy laws, especially given that Section I (B) of the Companion Report detailed numerous "Money Laundering Cases Involving Foreign Branches" encompassing London and/or the UK's overseas territories in 1987 (CR 1987:19-27). Of the three publicly available cases, two included examples of money laundering that had taken place through London or the Cayman Islands (United States v. Oscar Cuevas-Gamboa; United States v. Baker Lee Talbot). "Other Cases Involving Non-Public Information" (CR 1987: 26) detailed the use of the Cayman Islands and Hong Kong as vehicles for money laundering activities. As acknowledged by the US, "because of secrecy laws in many host countries, United States branch personnel are constrained from notifying U.S. authorities about suspected money laundering or reporting violations", but the Treasury believed that there was more that the foreign branches of its domestic institutions could do to "fulfil their obligation to assist U.S. law enforcement authorities in the fight against money laundering, especially drug 
money laundering" (CR 1987:14). For example, the Treasury announced plans to liaise with a "network of Customs attachés" and for those attachés to be a point of contact for personnel at foreign branches of US financial institutions, should they wish to inform the "appropriate attaché with such information within the confines of the host country's blocking and secrecy laws" (CR 1987:14). Simply put, under the auspices of the US Customs Service, the US was creating a network of Customs attachés who would collect information provided by informants from the banking and finance sectors in other countries, typically involving reports of "patterns of suspicious activity that may be evidence of money laundering, generally designed to circumvent Bank Secrecy Act requirements" (CR 1987:14). It is plausible, that in 1987, attachés served as conveniently placed informers in countries which possessed attractive laws - namely secrecy and tax - which were deemed harmful to the US economy. Indeed, in 1987, the US Customs Service mission included efforts to enforce the reporting requirements of the Bank Secrecy Act (US Customs, 1986:3). These efforts required, for example, collaboration with other US bodies such as the Office of Inspection and Control in 1985, and the Organized Crime Drug Enforcement Task Force in 1986, whereby Customs deployed special agents, analysts and clerks to assist in "disrupting major criminal organizations engaged in narcotics and money laundering" and the recovering of "illicit U.S. currency headed toward narcotic source and bank haven countries" (see for example Operation Buckstop 1985, in US Customs, 1986:11).

In 1987, and using attachés as a tool to compel US foreign branches to comply with Bank Secrecy Act requirements in the pursuit of dirty money, the Treasury needed to directly engage with those foreign-based financial institutions over which it recognisably had "little or no jurisdiction" (CR 1987:15), ${ }^{1}$ and would use its leverage with Interpol and its development of a Code of Conduct with the Basel Commission on Banking Supervision (BCBS) to help it achieve these aims. Certainly, the US had no jurisdiction over the bank secrecy laws of those UK overseas territories which hosted US financial institutions, and as will be shown from the data contained in the archives, the UK was adamant that the retention of bank secrecy and the rejection of extra territorial jurisdiction were priorities in any drug trafficking and AML negotiations with the US.

\section{US threats: The Basel Committee on Banking Supervision and Interpol}

The concept of the bankers' duty of confidentiality (commonly referred to as bank secrecy in the primary data archive), was viewed as an important component, indeed a pillar of, the UK's financial services industry in the 1980s, with Bruce Bucknell (ERD, FCO), corresponding that secrecy was "recognised as being upheld by an implied term of contract between banker and customer". Therefore, in response to the 1987 US Treasury Reports and the wider international war on drugs and dirty money, the UK needed to armour itself to ensure that bank secrecy was not watered down. If bank secrecy was weakened, this would have a negative impact on the UK's financial

\footnotetext{
${ }^{1}$ Foreign branches located in countries which enabled easy money laundering activity outside of the United States.
} 
services industry, both at home in the UK and more significantly, in its overseas territories.

Certainly, and as stated by the British Banker's Association (BBA) in response to questions raised by the Jack Committee on the subject of enquiries about the identity of new customers, ${ }^{2}$ the UK's banking and finance sector deemed it, "inappropriate to talk in terms of banks being under some sort of general duty (to unidentified parties)... as surely the only duty as such of a bank is the duty of self-protection - and this hardly needs to be embodied in a code of good practice" (excerpted from the secret, 1987 UK Treasury file. Q11 BBA). Simply put, the British banking and finance community felt that self-protection and reputation of the sector, outweighed US concerns to crack down on dirty money.

In 1987, the threats to the UK's banking and finance industry presented in the primary data, were to be found first, in the form of policy changing implications put forward by the US in its Draft Code of Conduct on money laundering - also referred to in the letters as the Recommended Code of Conduct for Financial Institutions Conducting Currency Transactions - and submitted to the Basel Committee on Banking Supervision (also referred to in the correspondence as the Cooke Committee). ${ }^{3}$ The second threat was identified in relation to Interpol's interest, support and "full and thorough consideration" of the above proposed code, coupled with Interpol's commitment to improve communication and cooperation between the law enforcement and financial communities at the international level - a policy making tactic that the US Treasury had been instrumental in developing, as they were behind the creation of the Working Group on Money Laundering created in 1986 at the Interpol Annual General Assembly. Both of these threats were deemed by the British to overstep the mark, in terms of extraterritorial implications and asserting legal obligations on banks, where none had existed before.

The Basel discussions on the proposed code of conduct were a cause of concern for the UK parties. In his letter dated 6 August to Richard Street (Economic Relations Department, Foreign and Commonwealth Office), Tom Harris (British Embassy, Washington DC) asked, "did you know about these discussions", concerning exclusive talks that the US had initiated with the Basel Committee on Banking Supervision and also Interpol. It is evident from the exchange of communication, that the UK was privy to some but not all of the transatlantic discussions concerning the exchange of information on money laundering. In his letters, Harris would also copy in associates from the Department of Trade and Industry, an assortment of Treasury Solicitors, and peers from the Bank of England at Threadneedle Street - notably the ongoing communications largely excluded representatives from the law enforcement community including W J Bohan of the Home Office, although J Potts of the C4 Division at the Home Office was copied into some of the correspondance .

\footnotetext{
The Committee on the Review of Banking Services Law was appointed in January 1987 under the Chairmanship of Professor R B Jack. Its brief was to examine the statute and common law relating to the provision of banking services in the United Kingdom to personal and business customers.

${ }^{3}$ Peter Cooke chaired the Cooke Committee at the Bank of International Settlements in 1987- more formally known as the Basel (then, Basle) Committee on Banking Supervision. He was responsible for formulation and introduction of the first risk-weighted capital rules for major international banks, now known as Basel 1 . He was also Head of Banking Supervision at the Bank of England.
} 
The concerns of Harris were echoed by Douglas Board from the UK's Treasury Chambers when he wrote to Graham Kentfield at the Bank of England on 20 August 1987. In particular Board recognised that US motivations to create a global AML regime, were strengthened by the "encouraging response [of Basel] to draft US principles of ethical behaviour in banking". Not only had the US initiated exclusive, inherently secretive talks with the Basel Committee, but the US proposals had been "tabled for "full and thorough" consideration at the Interpol General Assembly in October [1987]" with the conference aimed at creating steps which, "participating countries, bank regulatory authorities, and banks could take to improve enforcement efforts in response to money laundering" (TR 1987:5). As Board concludes in his letter to Kentfield, "[a]re the Home Office in a position to enlighten us about progress in Interpol?" and "[c]an the Bank say something about the Basel discussions?"

The Basel discussions referred to by Board, Kent, and also Richard Farrant at the Bank of England focused on a:

"[D]raft code of conduct which the US delegation put round the Basel Supervisors' Committee at its June meeting [1987]. We were asked for instant reactions. Ours was much like that of a majority of other countries around the table, to the effect that we could see no harm from a code of conduct along the lines of the draft, but thought that it would not do that much good. We would wish to study the details and also obtain the opinion of UK bankers". (Farrant to Board, 26 August).

The US code of conduct, under five briefly drafted articles, required British banks and those in other countries to: 1) ensure that robust identification policies were in place before a transaction was made; 2) terminate a financial relationship if required information was not provided or was deemed inaccurate, or if there were delays in providing the information; 3) prohibit direct or indirect assistance to customers seeking to deceive law enforcement; 4) report all instances of illegal activity; 5) develop and retain all documents relating to customer identification and ensure compliance with the code. The Basel Committee peddled the code of conduct as being "a general statement of principles that Bank Supervisory Authorities could encourage their banks to follow", ergo soft policy. However, as noted by Farrant to Board (26 August), "we noted that at one point the draft seemed to step from advocating good practice to asserting a legal obligation, where none seemed to exist at present. That must come out". Farrant concluded that enquiries into secrecy were considered "a low priority".

In light of Farrant's recommendation, the draft code of conduct was shared with the UK's most influential bankers under the auspices of the British Bankers Association (BBA). According to Farrant (26 August), the draft code was presented to the BBA "purely informally" and "they have given a predictably cool answer". The BBA, along with those at the Treasury would have viewed the code of conduct as indicating the US' intention to enforce US bank reporting requirements outside of the territory of the US. Although, as part of the compromise, the US Treasury Reports specifically warned the Congressional Committees against such attempts if the US was to "avoid the counterproductive results of increased enforcement of blocking statutes and serious confrontation between the US and other governments" (Tom Harris to Richard Street, 6 August - referencing the US Treasury Reports). 
The threat with which the UK viewed the US AML agenda, is evidenced by the mooted legislative responses available at that time, to block the enforcement of US policies, including the code of conduct. As noted by Christopher S Kerse (Department of Trade and Industry) in a letter to Douglas Board (HM Treasury) on 10 September, "[a] further matter which causes concern is the codes of conduct...I note these are described as "draft". Consideration should be given as to whether they could offend the Restrictive Trade Practices Act 1967 and/or other competition laws". It is also notable that Kerse copied in Treasury Solicitors including Steve Hyett in anticipation of US policy implications offending UK trading priorities. It was decided that the Protection of Trading Interests Act 1980 (PTIA) could be used to block US enforcement efforts if needed. The PTIA was created in light of US "juridical imperialism" in the context of US anti-trust laws (Kahn 1980:476). The PTIA, which received Royal assent on 20 March 1980, "represented the most recent attempt by Great Britain to curb the extraterritorial application of United States law" (Tsoris 1981:457). At the time of the PTIA's introduction, the British Secretary of State for Trade, John Nott, stated: "My objective in introducing this Bill is to reassert and reinforce the defences of the United Kingdom against attempts by other countries to enforce their economic and commercial policies" (Nott, Hansard 1979, column 1533). In discussing the Bill, Nott stated, "that the United States has shown a tendency in certain respects over the past three decades increasingly to try to mould the international economic and trading world in its own image" (Nott, Hansard 1979, column 1534). Indeed, it could be observed that in 1987 also, the US was trying to mould the international criminal legal system "in its own image". However, as will be shown, the UK would continue to resist extraterritorial expansion and policy obligations, deciding instead to draft detailed responses which would remain far short of the "basic and dramatic reform of international banking law" recommended by the aforementioned 1985 parliamentary committee.

On the 20 October, Richard Farrant of the Banking Supervision Division from the Bank of England, sent a letter to Douglas Board at HM Treasury. The correspondence was pencilled as "secret" at the top. Farrant included in his letter, a draft "considered response" (also deemed secret under the UK's Banking Act) from those at Threadneedle Street and their reaction to the "secret" code of conduct, including a "number of drafting points [from the British Bankers Association], which we consider should receive attention". The Bank of England's draft response stated that the "success of a code in the UK will depend very much on how reasonable its terms appear to the banks" - terms which we already know were greeted with a cool reception by the BBA. Moreover, the Bank of England cast doubt on the code as having "any real additional deterrent effect on money laundering through UK financial institutions", because requirements on banks "to verify the credentials of their customers" were deemed to be, "too onerous and have too little evident benefit to be imposed by a code of conduct; if considered necessary they should be imposed by law". Simply put, those at Threadneedle Street supported the idea of discouraging banks from "dealing with persons known or suspected to be disreputable", but were absolutely clear in their assertion that any proposed code "should not require them [banks] to take steps beyond the needs of their commercial self-interest to seek to verify the credentials of their customers". On 5 November and replying to Farrant, Board corresponded that he viewed the Bank of England's response as, "very reasonable". 
However,the Bank of England re-drafted their response to the US proposed code of conduct on 5 November and this time went into much more detail as to the acceptability of the terms. In the re-draft, the Bank of England stated that it did not possess "specific powers covering money laundering through banks", even though it acknowledged it was the "regulatory authority over UK banks". Conversely, while the Bank of England did not consider itself in possession of powers to regulate money laundering through UK banks, the primary correspondence data indicates that those at the Bank of England did consider themselves in possession of policy making powers at the level of international law enforcement. The haughty, self-serving interests of the UK's banking industry are evident in the Bank of England's expanded and re-drafted response. For example, the Bank of England emphasises "that the existence of the code is much less relevant than its acceptance by the banking community as constituting normal practice", again underlining a thread of this paper; that AML - essentially criminal law policies, required approval by the banking industry first, before being considered by law enforcement and relevant policy makers. In essence, in 1987, British bankers were responsible for shaping the AML framework for the UK and indirectly for the international financial community: British bankers were deciding on matters of national and international criminal law.

The proposed code of conduct put forward by the US, with its reporting obligations, threatened the bank secrecy practices of the UK industry, and to this end the Bank of England's response went into detail as to why it was refuting the policy recommendations - a double bluff if you like - asserting that the reporting requirements included in the US code "will provide very limited knowledge of the customer" and that "nothing less than intimate knowledge of a customer would enable a bank to determine whether he was likely to money launder". Yet, in reality, it was this "necessary intimacy" of customer knowledge which the Bank of England and the BBA did not wish to concern themselves with - and the UK was able to undermine the US code of conduct, by drawing attention to the fact that the code provides "far less than the necessary intimacy". In this dialogue, the Bank of England succeeded in creating a veneer of respect for the AML movement, by establishing that the US provisions were actually not strong enough, while at the same time safe in the knowledge that the BBA would never agree to extending the scope of the provisions to include obligations on banks to intimately know their customers: "Is the likely benefit worth the extra costs to the banks arising from being required to research the credentials of their customers more than is required by the existing law and their commercial self-interest?". As noted by Goodhart (2011:286) the comments from the BBA and the Bank of England were hostile interestingly, Switzerland, France, Luxembourg, Belgium, Canada and the Netherlands were in favour of the code (Goodhart 2011: 286). Ultimately the UK's hostile response boiled down to one point, that the Bank of England would not sponsor a code of conduct which it could not enforce, and was doubted therefore to "have any real additional deterrent effect [in light of the existing legal provisions at the time] on money laundering through UK financial institutions" considering that, "UK financial institutions have no obligation to ensure that payment systems are not being used to deceive or defraud government agencies". While this article's intention is not to detail the evolution of the Basel Core Principles of Banking Supervision, it is noteworthy that the US' initial attempt at organising a code of conduct, is considered to be "the first set of BCBS principles on money laundering" (Goodhart 2011: 286). As noted by 
Goodhart (2011:288), the term code of conduct was "softened" to become the "Statement of Principle" at the behest of the UK and also France - the former most likely rejecting the code of conduct title because of the inferences of obligations which can be drawn from it. Thus the US draft code of conduct, was softened and became the first set of principles distributed to a mix of non-G10 Supervisors and also G10 banks in December 1988 and January 1989 respectively. ${ }^{4}$ Notably, the words "illegal activity" were replaced with "criminal activity" to "narrow the scope of the exercise, excluding tax evasion for example, from its ambit" (Goodhart 2011:288). It is also notable that the creation of a policy which did not include tax evasion as a crime, served to reinforce the legitimacy of contemporary offshore banking practices which allowed a range of economic crimes to flourish in overseas financial hot spots, such as the Cayman Islands.

By 1988 the proposed code of conduct had been watered down, however, it remained that in 1987, the UK was troubled not only by the US code of conduct and the potential obligations placed on UK banks to intimately know their customers, but also by the potential involvement of Interpol in the international policing of financial organized crime.

\section{Interpol kept in its place}

The purpose of this paper is not to delve into the inner workings of Interpol (a politically neutral inter-governmental institution which facilitates international law enforcement cooperation and is governed by international law (Interpol 2020)), however, it would be remiss of the authors not to mention the part that Interpol played in the unfolding AML dialogue of 1987, contained in the primary data archive. Although not a norm making body, Interpol possessed the power to bring together the law enforcement partners of different countries, under the shared goal of cooperation and information sharing in the fight against crime. It has already been mentioned that the US Treasury Report (1987) contained an initiative to create an Interpol Working Group on money laundering to improve cooperation between countries and their banking and financial institutions and law enforcement bodies (Resolution AGN/55/RES/18). The working group was established in the wake of the 55th Interpol General Assembly in Belgrade, Yugoslavia in 1986. By 1987, the working group was considering five additional recommendations which had been submitted by US Representative Robert B Serino, Deputy Chief Counsel (Operation) at the Office of the Comptroller of the Currency.

The recommendations were included in the Draft Memorandum of Co-operation of the Interpol Working Group to Improve Cooperation Between the Law Enforcement and Banking Communities. The additional five objectives which were sought by the US broadly dictated that countries' representatives to Interpol should recommend to bank

\footnotetext{
${ }^{4}$ The Group of Ten is made up of eleven industrial countries (Belgium, Canada, France, Germany, Italy, Japan, the Netherlands, Sweden, Switzerland, the United Kingdom and the United States) which consult and co-operate on economic, monetary and financial matters. The Ministers of Finance and central bank Governors of the Group of Ten meet as needed in connection with the meetings of the International Monetary Fund and the World Bank. https://www.bis.org/list/g10publications/
} 
regulatory authorities, that their country's laws criminalise money laundering and that bank personnel should be vetted using Interpol facilities. In particular, it was proposed by the US that countries should adopt a code of conduct (such as the proposed code of conduct discussed above) whereby all bank regulators, banking associations, banks and law enforcement agencies, establish a position in their offices to act as a filter or point of contact for law enforcement matters - akin to the system of attachés used by US Customs . Further, that banks and bank associations should use Interpol facilities to vet personnel before they were employed or able purchase a banking licence. To achieve these aims, Interpol sought to work closely with bank regulators to create regulations which would put obligations on banks to report possible criminal activities.

On 11 September 1987 Chris Hudson of the Home Office wrote to Douglas Board at Treasury Chambers with regards Interpol's consideration of the US proposals. Hudson wrote that:

"The Working Group held its first and so far only meeting in March 1987... the UK was represented by two police officers from the Metropolitan Police and I understand that the meeting finally adopted a resolution... I understand that the Americans tried to expand this resolution with the addition of the objectives... but this was defeated because other countries, including the UK delegation, felt that such proposals went beyond Interpol's remit".

In a letter dated 20 August Douglas Board had previously corresponded with Graham Kentfield of the Bank of England concerning the US initiatives to confiscate the proceeds of drug trafficking offences. In particular, Board was concerned that the Interpol General Assembly meeting tabled for October 1987, would mean "full and thorough consideration" of the aforementioned US proposals: proposals which would focus on banking regulatory authorities. Board, representing the financial and banking community, writing to Bank of England officials Kentfield and Farrant, suggested:
"[A] meeting to give the Home Office some marching orders so that INTERPOL stops passing resolutions such as: '...believing that these acts of fraud against financial institutions have reached epidemic proportions and are now a threat to the economy of some countries... believing that the unabated fraudulent attempts against financial institutions may destroy the confidence in national banking systems"”. (Emphasis original.)

This final part of Board's letter demonstrates the tug of war existing between those who worked in and profited from a banking sector which turned a blind eye to dirty money, and those members of the international policing community, who found their attempts to clean up were frustrated by bankers, politicians and government officials. In fact, the primary data correspondence between the letter writers, made it clear that Interpol was not a policy making body but existed only as a body to facilitate cooperation between law enforcement agencies. The British position was that attempts to step on the toes of policy makers would be outside of Interpol's jurisdiction.

Ultimately, and in a similar vein to the watering down of the US proposed code of conduct which was delivered to the Basel Committee (discussed above), "the US was successful in getting its five additional points added to the resolution although the text 
was amended in a number of ways to make it more realistic" (Hudson, Home Office to Board at Treasury Chambers on 23 December 1987). Resolution AGN/56/RES/11 on the Co-operation between the banking and financial institutions and associations and law enforcement agencies, was consequently drafted in such a way so as to accommodate the wishes of the UK's banking and finance sector, that Interpol should "avoid straying into territory in which it is unable to exert direct influence, such as regulations governing banking practices and procedures" (Hudson to Board, 23 December). Simply put, the British banking community was reluctant to have a law enforcement advisory agency contribute to the construction of the AML template - especially, if those proposals were deemed to be harmful to the interests of the UK's financial community. Amendments were ultimately made to the additional objectives, including the removal of words and/or phrases which would create obligations for UK banks and financial institutions. Notably, Item 9 of the Resolution specified the adoption of AML laws but was watered down to reject the mention of sanctions, and Item 7 was made palatable by encouraging banks to "take necessary security precautions" (AGN/56/ RES/11), "rather than suggesting that Interpol sources should be used to vet all personnel" (Hudson to Board, 23 December). The additional objectives proposed by the US for inclusion in the relevant Resolution, would be amended to such an extent that the enforcement of AML policies put forward by Interpol would be rendered ineffective, as the resolution would accommodate the banking community's wish to police their own industry. As noted by Hudson to Board, "I expressed my concern to the police members of the delegation that Interpol should avoid straying into territory in which it was unable to exert direct influence, such as regulations governing banking practices and procedures".. At the end of the process, Interpol's General Secretariat was reduced to hoping “...banks would make a practice of not accepting "hot money"'. (General Secretariat 1987:4).

\section{A world fit for money laundering}

Since the creation of US anti-organized crime and anti-drug policies in 1970, and the accommodations reached between American and British policy shapers in the late 1980 s - as revealed by the discussions in the previous sections - there has been a spawning of soft and hard policy documents over the past thirty years. These policy making efforts fully embrace the notion that the implementation of international AML frameworks, is all that is required to rid the world of a myriad of high-profit generating organized crimes, including drug trafficking, human trafficking, corruption and terrorist financing. International legal instruments which seek to target organised crime by undermining the financial bases of criminal organisations, include the: United Nations Convention Against Illicit Traffic in Narcotic Drugs and Psychotropic Substances (1988, Vienna), the United Nations Convention for the Suppression of the Financing of Terrorism (1999, New York), the United Nations Convention Against Organized Crime (2000, Palermo), the United Nations Convention Against Corruption (2003, New York), and the Financial Action Task Force Recommendations concerning International Standards On Combating Money Laundering And The Financing Of Terrorism \& Proliferation (2012, Paris). Despite the raft of legislation which has been produced 
since the late 1980s, "experts still ponder how to implement an AML/CFT [combating the financing of terrorism] regime that works" (Blickman 2009:5-7).

The implementation of an AML regime that actually works, will be impeded as long as lax regulations in offshore financial centres, coupled with low or no tax regimes and strong financial secrecy policies remain in place. These policies, which reflect the deregulatory tendencies in recent decades, are disposed to banking corporations, governments and criminal organisations alike and are responsible for countless financial scandals past and present. Such policies served to undermine the initial crime control norms and objectives orchestrated by the Nixon administration in the 1970s, and the expansion of these policies embodied by the 1987 discussions explored in this paper; discussions which were called for as a response to the policy implications of Reagan's 1982 pledge to, "end the drug menace and cripple organized crime" (New York Times 1982).

The AML regime that emerged from the accommodations between the US and the UK in the late 1980s, has made little impact on the extent of money laundering at the global level and the use of tax havens around the world to hide riches, as evidenced by a succession of revelations against big Western banks and corporations, contained in the Offshore Leaks Database compiled by the International Consortium of Investigative Journalists. As this article has shown, the objectives of Nixon's wars on organized crime and drugs and the concomitant war on dirty money in the 1970s, were grounded in flawed policies and then undermined completely by the compromises reached between the UK and the US in the Thatcher-Reagan era of organized crime control, as documented in the archive data used for the research.

In 1987, under the Reagan administration, the US was determined to expand the war on drugs and crack down on jurisdictions which catered for criminal clientele who wished to wash their dirty money through the foreign branches of US financial institutions. As explored above, although the US was the public face of the war on dirty money and thus the leader of AML policy at the wider, international level, the Reagan administration recognised the need to retain cordial relations with the UK, even if the UK's secrecy jurisdictions were those proving most harmful to US ideals in terms of possessing laws which enabled US citizens to breach the Bank Secrecy Act. Both the US and the UK, ultimately undermined the international AML framework they helped to construct. While the intention may not have been to subvert their own AML policies, it is clear to the authors of this paper, that the US and UK prioritised economic power and relations with the banking sector, above effective, international efforts to combat organized crime.

The prioritisation of retaining economic power in the context of the financial services industry, was of the utmost importance to the US and the UK - neither country wanted to compromise their dominant positions in the global financial architecture. In particular, as has been shown, those at the very top of the financial services industry in the UK were essentially privy to the processes involved in creating and shaping international criminal law policies. The US and UK would seek to balance their financial interests with the moral crusades being waged against organized crime, drugs and drug money laundering. Trying to balance these priorities has ultimately led to the monumental failure of the current AML framework. As has been argued by Young (2013), it is nigh on impossible to have secrecy laws and criminal confiscation laws operating effectively in the same jurisdiction; and the same applies for the construction 
of the international AML framework. The retention of financial secrecy as a component of the wider priority of a strong financial services industry in the UK, is starkly juxtaposed with the rhetoric of stopping the transnational flow of dirty money - both in 1987 and the present day.

Much of the world's dirty money gets washed in the financial institutions of two of the leaders in the global campaign against organized crime and dirty money - the US and the UK. Both the UK and US have retained strong financial secrecy laws in various jurisdictions. Retention serves the purpose of strengthening trade for the financial services industry, while obfuscation continues to allow for countless opportunities for commercial gain - legal and illegal - for both countries. Few of the inconvenient realities about the illegal activities collectively known as organized crime and transnational organized crime are allowed to inform the public or their representatives in government. All are trapped in discourses of national and international security that do not permit informed discussion. The world's regulatory regimes remain too weak to check organised business crime. The world's borders remain too porous to check smuggling in legal or illegal goods. And bankers in powerful nations remain as keen on money as they always have been, whether or not it is "clean" or "dirty". Whistleblowing on any of the above is not encouraged. The incentives to turn a blind eye remain much higher.

Acknowledgements The authors would like to thank Laurie Woodiwiss for his contribution towards research for this article.

Open Access This article is licensed under a Creative Commons Attribution 4.0 International License, which permits use, sharing, adaptation, distribution and reproduction in any medium or format, as long as you give appropriate credit to the original author(s) and the source, provide a link to the Creative Commons licence, and indicate if changes were made. The images or other third party material in this article are included in the article's Creative Commons licence, unless indicated otherwise in a credit line to the material. If material is not included in the article's Creative Commons licence and your intended use is not permitted by statutory regulation or exceeds the permitted use, you will need to obtain permission directly from the copyright holder. To view a copy of this licence, visit http://creativecommons.org/licenses/by/4.0/.

\section{References}

Anti-Drug Abuse Act of 1986, Pub. L. No. 99-570, 100 Stat. 3207 (codified as amended at 21 U.S.C. SS 841904 (2012))

Atkinson P, Coffey A (1997) Analysing documentary realities. Sage, London

Baldacchino G, Milne D (eds) (2000) Lessons from the political economy of Small Islands: the resourcefulness of jurisdiction. Macmillan, Basingstoke

Blickman T (2009) Countering illicit and unregulated money flows: money laundering tax evasion and financial regulation Transnational Institute

Blum RH (1981) Offshore money flows: a large dark number. J Int Aff 35:1

Ceresola RG (2019) The U.S. Government's framing of corruption: a content analysis of public integrity section reports, 1978-2013. Crime, Law and Social Change vol. 71, Issue 1

Committee on the Review of Banking Services Law (Jack Committee): Report and Government Response (1987-1990) The Report and the government response to it were published in command papers (Cmnd 622 and Cmnd 1026 respectively)

Cox D (2014) Handbook of anti-money laundering. John Wiley \& Sons, Chichester

FATF (2012) Best practices paper: best practices on confiscation (recommendations 4 and 38) and a framework for ongoing work on asset recovery. FATF, Paris, France 
FATF (2016) Guidance on the criminalisation of terrorist financing (recommendation 5). FATF, Paris, France Fisher J (2002) Recent development in the fight against money laundering. Journal of International Banking Law 17(3)

General Secretariat, Working group to improve co-operation between the law enforcement and banking communities, Interpol, $56^{\text {th }}$ general assembly session, Nice, $23^{\text {rd }}-27^{\text {th }}$ November 1987

Goodhart C (2011) The Core principles of banking supervision. In: The Basel (ed) Committee on banking supervision: a history of the early years. Cambridge, Cambridge University Press, pp 1974-1997

Greer C (2013) Crime and media: understanding the connections. In: Hale C, Hayward A, Wahadin A, Wincup E (eds) Criminology. Oxford University Press, Oxford

Hansard, House of Lords, Rhodesia: Sanctions And USSR Imports, 19 July 1979, Volume 401

Harris J (2002) The correspondence method as a data-gathering technique in qualitative enquiry. Int J Qual Methods 1(4)

House of Commons, Fifth Report from the Home Affairs Committee, Session 1984-85, Misuse of Hard Drugs (Interim Report). Her Majesty's Stationary Office: London

Interpol <https://www.interpol.int/en/Who-we-are/Strategy/Strategic-Framework-2017-2020> accessed 5 March 2020

Interpol Resolutions AGN/55/RES/18, 1986; AGN/56/RES/11, 1987

Kahn TJ (1980) The Protection of Trading Interests Act of 1980: Britain's Response to U.S. Extraterritorial Antitrust Enforcement. Northwestern Journal of International Law \& Business, vol. 2, no. 2, Autumn 1980

Leong A (2007) Chasing dirty money: domestic and international measures against money laundering. Journal of Money Laundering Control 10(2)

Levi M, Reuter P (2006) Money Laundering. Crime and Justice, vol. 34, no. 1

Lord Mansfield's dictum (1775) found in Holman v. Johnson 98 Eng. Rep. 1120 (K.B. 1775)

Nadelmann E (1993) Cops across Borders: the internationalization of U.S. criminal law enforcement, University Park, Pennsylvania: the Pennsylvania State University press

Naylor RT (2002) Wages of crime: black markets, illegal finance, and the underworld economy. Cornell University Press, New York

New York Times, 15 October 1982

Nott J, House of Commons Hansard, Commons Chamber, Orders Of The Day, Protection Of Trading Interests Bill, 15 November 1979, Volume 973. House of Commons 973 PARL. DEB., H.C. (5th ser.) 1533-34 (1979)

President's Commission on Organized Crime (1984) The cash connection: organized crime, financial institutions, and money laundering. Government Printing Office, Washington D.C

Protection of Trading Interests Act 1980

Robinson J (1995) The laundrymen: inside the World's third largest business. Pocket Books, London

Schott PA (2006) Reference guide to anti-money laundering and combating the financing of terrorism second edition and supplement on special recommendation IX The International Bank for Reconstruction and Development/The World Bank/ The International Monetary Fund

Senate Committee. S. REP. No. 130, 99th Cong., 1st Sess. (1983) (entitled "Crime and Secrecy: The Use of Offshore Banks and Companies"); United States. Congress. Senate. Committee on Governmental Affairs. Permanent Subcommittee on Investigations. Government Printing Office: Washington D.C.: [Supt. Of Docs., U.S.G.P.O., distributor], [1983] 98th Cong., 1st Sess. (Comm. Print 1983). See Also R. Gordon, Tax Havens And Their Use By U.S. Taxpayers 197-214 (1981)

Sharman JC, Chaikin D (2009) Corruption and anti-money-laundering systems: putting a luxury good to work. Governance 22(1)

Souster RJ (2013) Second edn) Financial crime and money laundering. Global Professional Publishing, Cranbrook

Spector M, Kitsuse JI (2001) Constructing social problems. Transaction Publishers, New Brunswick, NJ

Stessens G (2000) Money laundering: a new international law enforcement model. Cambridge University Press, Cambridge

Tsoris SA (1981) Section 6 of Great Britain's Protection of Trading Interests Act: The Claw and the Lever. Cornell International Law Journal, vol. 14, no. 2, Summer 1981

UK Treasury file, International Money Laundering: Banking Secrecy, 1987 T555/19 FIM-BNK /A /0012/001 (Document identifier, The National Archives)

United Nations (2007) Global Programme against Money Laundering, Proceeds of Crime, and the Financing of Terrorism (GPML)

US Customs, A Report on the Activities of the U.S. Customs Service During Fiscal Year 1986, March 251987 
US Treasury Report and Companion Report. International Information Exchange on Money Laundering; and Money Laundering and the Bank Secrecy Act: The Question of Foreign Branches of Domestic Financial Institutions. Reports submitted by the Secretary of the Treasury to The Committee on Banking, Finance and Urban Affairs and The Committee on the Judiciary of the United States House of Representatives and to The Committee on Banking, Housing and Urban Affairs and The Committee on the Judiciary of the United States Senate, July 291987

Van Duyne PC (2008) Serving the integrity of the Mammon and the compulsive excessive regulatory disorder, Crime, Law and Social Change, vol. 52, no. 1

Woodiwiss M (2005) Gangster capitalism: the United States and the global rise of organized crime. Constable and Robinson, London

World Bank. Reference Guide to Anti-Money Laundering and Combating the Financing of Terrorism, Chapter V Legal System Requirements at p. v2 (see Schott above)

Young MA (2012) Banking secrecy and offshore financial centers: money laundering and offshore banking. Routledge, London

Young MA, Woodiwiss M (2019) Organised crime and security threats in Caribbean Small Island developing states: a critical analysis of US assumptions and policies. The European Review of Organised Crime 5(1)

Publisher's note Springer Nature remains neutral with regard to jurisdictional claims in published maps and institutional affiliations. 